UDC 811.161.1/ 821.161.1

DOI $10.15421 / 462012$

\title{
LANGUAGE STYLISH BASES OF CATEGORIES IMPLICITNITY AND IDIOSTYL F. M. DOSTOVSKOGO
}

Yu. Shepel

Doctor of Philology, Professor, acad. NASHA of Ukraine, Professor of the Department of translation and linguistic training of foreigners,

Oles Honchar Dnipro National University

123zub@ua.fm

orcid.org/0000-0002-3182-3128

Introduction. The issue of correct decoding of hidden meanings has recently acquired a new meaning in the context of idiostyle, where in the foreground is the connection between language and thinking, linguistic consciousness and the author's picture of the world. The interaction of culture and the semantic space of the language in the idiostyle is manifested especially clearly when decoding subtext information, in connection with which the concept of idiostyle as a linguistic means of realizing an idiolective personality appears in the center of linguists' attention by eliminating socialist realism, recognizing the versatility of the creative process, author's stylistics, etc. So, the interest in the idiolective personality in the language is quite natural, since the idiolective personality is realized against the background of the picture of the world and breaks in itself and through itself both the nominations of a specific temporary (sociopolitical, cultural, spiritual) meaning, and the general language level. So the relevance of our research stems from the interest of modern humanitarian science to clarify many issues related to the linguistic personality, artistic creativity and the mechanisms of generating texts. The object of research in the article is the literary texts of F. M. Dostoevsky, in particular "Crime and Punishment" and "The Brothers Karamazov", in which the relationship between the language and the personality of the author is revealed to a greater extent, namely the communicative-pragmatic category of implicitness.

The subject of this research is F. M. Dostoevsky's idiostyle, which we understand as a complex system of typical author's models that regulate the reader's reflection and lead him to an adequate understanding of the existing and hidden (implicit) meanings that are foreseen in the text. The purpose of the article is to define the concept of "idiostyle" and consider various approaches to this concept due to the peculiarities of the creative manner of writing of F. M. Dostoevsky, in particular the category of implicitness.

Methods and methodology of investigation. In this work, we resort to such methods as descriptive and linguastylistic analysis, because the question of idiostyle in the last decade has acquired a complex character, in accordance with which the analysis of F. M. Dostoevsky's idiostyle requires a multilevel approach. The research methods are determined by the concept of studying the integrity of the artistic image of a work of art, determined by the intersection of semantics and stylistics. To determine the implicative properties of the details of the writer's works, in addition to analyzing the stylistic context, the author turned to the method of lexical transformation and analysis of dictionary definitions as variants of component analysis. through:

Results and discussion. Currently, linguists propose to consider idiolective features

- standard linguistic personality, which reflects the average norm of a literary normalized language;

- non-standard linguistic personality, which is determined by deviations from the wellestablished interpersonal and intercultural communicative norms.

Therefore, inferences about the signs of a linguistic personality can be carried out only on the basis of a specific linguistic analysis of the texts he created.

Here it is worth noting the following. First, modern linguistics, focusing on human cognitive 


\section{Ukrainian sense. 2020. ISSN 2313-4437}

needs, moves from text analysis to discourse discussion, where psychological, extralinguistic and cognitive human knowledge are important. Second, the process of reading is still seen as a dialogue between writer and reader. Third, discourse is understood as a complex communicative phenomenon that contains, in addition to the text, extralinguistic factors that are important for understanding the text, because discourse captures all the diversity of language, mentality and national-cultural features of the communicative situation.

The main manifestation of implicitness in discourse is its cognitive status, focus on the background knowledge of the recipient and the hidden emotional and psychological impact on the reader.

Thus, we perceive the discourse of F. M. Dostoevsky as the nature of the exposition of the writer's works and its distinctive linguistic features. Idiodiscourse is a communicative-artistic space of the author and the reader, which in the aggregate and interaction of all its aspects forms a holistic communicative environment, in which all who participate in the process of communicative activity are immersed. In such a communicative-artistic space, an idiostyle is formed - individual-authorial features of world perception and textual activity, which are reflected in the text as a means of communication, including the organization of a dialogue with the reader.

The fictional text is distinguished by a unique author's individuality. Therefore, the idiolective personality demonstrates a unique workshop of the individual state of the language, which allows us to talk about the author's idiostyle. At the present time we can say that the concept of "idiostyle" is still in a state of scientific development, therefore, the existence of various definitions of idiostyle is quite understandable. However, in my opinion, it is quite possible to agree with the opinion of linguists that idiostyle is an invariant personal meaning, has a conceptual basis.

The style of the author is reflected in the style of the artwork. It largely determines the communicative and aesthetically determined principles of text organization, the selection and compatibility of language means, the choice of stylistic techniques. The concept of idiostyle also includes, against the background of the general language communicative structure, the nature of the associative-semantic deployment of the text, which determines its structure, pragmatics and semantics. Therefore, the idiostyle realizes the author's linguistic personality, his worldview through the individual use of language in the aesthetic sphere.

The purpose of any text, as you know, is to influence a person. That is why F. M. Dostoevsky activates all means (speech and non-speech) that ensure the creation of the necessary projection of the text in the reader's imagination. A coherent text is determined not only by metaphysical, but also by specific ideas of a person about the picture of the world. In this regard, structures that bring additional meaning are of particular importance. One of the most important categories of the text - information content - is responsible for the formation of such structures.

Any text has content-conceptual information, the components of which are non-verbal (subtext) information and verbal (factual) information. Misunderstanding of subtextual information leads to erroneous or complete misunderstanding of the text. Considering that the content side of F. M. Dostoevsky's author's idiostyle is connected with the religious and historical-philosophical views of the writer, for the creative manner of F. M. Dostoevsky is indicative of a deep penetration into the essence of the phenomenon described by the author, its interpretation and detailed depiction. The Bible had the greatest influence on F. M. Dostoevsky, therefore, in the writer's idiodiscourse, we often observe biblical allusions and quotations, folklore, literary, mythical borrowings. The linguistic features of F. M. Dostoevsky's idiodiscourse can also be seen at the level of syntax, namely, the use of complicated structures, mainly three-component ones. The syntactic structure of the language in the novels "Crime and Punishment", "The Brothers Karamazov" is represented by a large number of repetitions, symbols, inversions.

Spatio-temporal relations in the text of the novel are maintained according to the chronotope principle.

The literary text of the novel is characterized not only by integrity and coherence, but also by such signs as cognitiveness, connotation, informativeness, communicativeness, which together 


\section{Ukrainian sense. 2020. ISSN 2313-4437}

characterize the textual structure of the novel. Therefore, an adequate perception of F. M. Dostoevsky's idiodiscourse requires revealing hidden, conceptual information.

The presence of two types of information - obvious and hidden - for a writer is kept at two levels of speech utterance - explicit and implicit.

Explicit can be considered a form of thought that is expressed directly, explicitly and openly stated by the speech unit or system of units without their transformation (Kornienko, 1996). By implicit we mean a special expression of thought, which does not directly have a material expression, but is meant and expressed through the interpretation of the text. Implicitness acts as an asymmetry of content and expression, when the opinion / expression contains much more information than the speech expression (Ermolenko, 2001).

Statements with a hidden subtext, where most of the information is missing, but understandable, have always existed, although the object of in-depth study became only in the seventies of the XX century (Arnold, 1982; Baghdasaryan, 1983; Kukharenko, 1980; Nikitin, 1988). Let us briefly dwell on this question.

Initially, the goal of scientists was to try to determine the substantive truth of the sentence (Khvorostin, 2006: 45). Therefore, the theory of implicitness acquired its development under the influence of the "philosophy of ordinary language", and since the tendency to study the cognitive mechanisms of the human brain has actively manifested itself in domestic linguistics, implicitness has become the object of study in the theory of speech (Austin, 2011). Among those who provided formulations of implicitness was V. Baghdasaryan. He considered explicit, or present, that "has its own verbal expression, and implicit, or hidden, that which has no verbal expression, but is understood through an explicit plan of expression" (Baghdasaryan, 1983: 45). Therefore, it can be argued that an implicit statement may be transmitted in whole, in part, or no verbal expression at all. That is, it is a form of expression of thought mediated by other factors. Explicitness is considered to be the main line of utterance, and implicitness is considered auxiliary, secondary (Baghdasaryan, 1983).

The theoretical ideas of V. Bagdasaryan drew criticism from P. Parshin, who noted that implicitness cannot be talked about from the standpoint of theory, but it should be considered only within communication, since the complexity and importance of the information presented in the text is called, and only the background knowledge of the recipient allows understand hidden information (Parshin, 2000).

Scientists associate implicitness with the presence of gaps in the text-omissions, omissions, violations of speech norms. That is, the reader should try to understand the segment of the text that contains the anomaly. Any deviation from principles and situational norms can become an impulse to search for subtext:

1) a lacuna in the text is the implication of a fact;

2) a lacuna in the text - the implication of a logical connection;

3) inconsistency of the statement - the implication of the personal relationship of the addressee to the message;

4) inconsistency between statements and actions;

5) inconsistency between the expression and the role of the addressee;

6) inconsistency of the direction of the statement with the main parameters of the hidden content and (Dolinin, 1983: 40).

M. Fedosyuk, presenting his concept of implicitness, believes that the interpretation of the implicitness of something unspoken, hushed up, but recognizable is absolutely correct, and argues that the implicit meaning does not have direct expression, but follows from the explicit meaning of a speech unit as a result of its interaction with knowledge of the recipient (Fedosyuk, 1988).

I completely agree with the opinion of N. Anokhina, who suggests that implicit content components, which are not reflected in the external, but are present in the internal structure of the text, are integral elements of the deep form of the text (Anokhina, 2010).

Thus, the concepts of implicitness that currently take place in linguistics (Dolinin, 1983; Kukharenko, 1988; Ermakova, 2010; Hvorostinok, 2006), differ slightly in their semantic meaning. 


\section{Ukrainian sense. 2020. ISSN 2313-4437}

One thing unites them - there is implicitness when something is stated in a hidden, indirect way.

Analyzing the degree of study of the category of implicitness, it can be noted that this category was studied at different levels:

- grammatical (at the level of morphology and syntax)

- speech (designed for different levels of the linguistic system)

- textual and discursive (analyzed as a structurally meaningful connector of text segments);

- communicative (as a representation of latent meanings during interactions among communicants)

- logical-linguistic (as a special way of expressing thoughts) (Ivanishyn, 2006).

Implicitness in the context of text linguistics is a textual reflection of the general law of linguistic economy and is manifested in the mechanisms of compression. Implicitness is the answer for the formation of the textual whole as a unity of the plan of content and the plan of expression and determines the development of the stylistics of the text in the diachronic aspect (Shelud'ko, 2016).

Therefore, in our opinion, implicitness is a linguistic category that is responsible for creating additional meanings and subtexts, because implicit constructions have a deeper content and do not reflect all the diversity of the content of the statement, unlike traditional constructions ${ }^{1}$.

Linguistic textology, the center of which is the study of the speech text as a tool of human activity in a specific extralinguistic context, allows us to explain many linguistic phenomena that have not been resolved for a long time. In this regard, the study of the structure and meaning of the semantic categories of the text acquires special relevance, because the semantic content of the text is related to the extra-linguistic situation and thereby is a reflection of reality.

The content of the text / statement is usually divided into nominative and communicative. The nominative meaning of the statement tends to be explicit, and the communicative - to implicit. Nominative content is never completely limited to what is said, but always at least something remains in the subtext, and the communicative meaning has its means of expression and is always presented in one way or another in the explicit sense of the statement. So in the explicit and implicit sense there are the same levels: nominative and communicative subtext.

Analyzing the main provisions of the theory of implicitness, one can notice that the generation of implicit content is a universal means of artistic and literary influence. It is implicitness that is used by F. M. Dostoevsky as a certain discursive strategy (both positive and negative) of influencing the reader. Since the principles of implicitness are based on the principles of linguistic economy, the replica / word can act as the main means of implementation in F. M. Dostoevsky's idiodiscourse (Arustamyan, 2011). That is why, we consider the concept of implicitness both when analyzing the implicit impact (manipulation) on the reader, and during the identification (decoding) of the implicit content components of the message (subtext, intertextual connections, formal organization of the text).

Implicitness in F. M. Dostoevsky's idio discourse reveals itself in the latent expression of the semantics of communicative units during their interaction with explicitly expressed content (Prosyanikova, 2004). This common property is inherent in all units of the language system and can affect various text levels. It is the asymmetry of speech signs, linguistic dualism that gives rise to implicitness in F. M. Dostoevsky. That is, due to the close connection with semantics, and subject to adequate perception by the reader, implicitness realizes the main intention of the writer and reveals the conceptual-subtext content of the text.

System-linguistic implicitness is responsible for the degree of actualization of grammatical semantics and activates semantic categories, which are semantic invariants - modality, temporality, personality, aspectuality (Bondarenko, 2006: 24).

Implicitness can be a means of economy and rational use of language by a writer. Thus,

\footnotetext{
${ }^{1}$ Compare: The main signs of implicitness as a speech category include non-ligatory, secondary meaning, that is, its extraction from the explicitness and a special way of expression, namely, the absence of material meaning, the presence of the main sources of detection (subtext, implication, presuppositions) and the ability to appear in the text a semantic connector (Ivanishyn, 2006).
} 


\section{Ukrainian sense. 2020. ISSN 2313-4437}

L. Lisochenko testifies to the connection between implicitness and semantics and speaks of the asymmetric dualism of implicit statements. Implication relations and implicitness of speech expression in the semantic structure of an utterance can be side facts, therefore the implicit semantics of an utterance is associated with its presupposition (Lisochenko, 1992).

Implicitness creates a discrepancy between the plan of expression and the plan of content in F. M. Dostoevsky's idiodiscourse and finds its concrete realization in various speech and nonspeech phenomena.

Implicitness can be viewed as "the presence of a meaningful absence", but here it is necessary to consider whether the writer takes into account such "absence". Implicitness can be used intentionally or accidentally. Therefore, M. Nikitin, for example, does not consider it appropriate to analyze randomly used implicit constructions, because they represent side information of communicative acts. But such an approach requires a search for an answer regarding the distinction between a randomly used implicit construction and a deliberate one (Nikitin, 1988).

Implicitness rests on the general knowledge of the writer and reader and on cultural traditions and cultural connotations (Khvorostin, 2006), therefore, knowledge about the world (background knowledge) is necessary for the perception of the text, since the task of reproducing the full content of the text makes it necessary to take into account fragments of content that are associated with the actualization of general ideas about the world.

In particular, the study of implicitness in F. M. Dostoevsky's idio discourse should be carried out in the context of anthropological linguistics, which allows one to involve psychology, sociology and other sciences to study the inner world of a person and brings to the fore the pragmatic aspect in the study of linguistic phenomena. It is important for understanding implicitness to distinguish between the concepts of "meaning" and "meaning", since meaning is possible, because meaning exists, and meaning exists for the sake of meaning (Miloserdova, 2011: 728).

On the other hand, implicitness in F. M. Dostoevsky's idio discourse performs an important text-forming and informational function. From the standpoint of cognitive interpretation, the cognitive structure of an utterance is always presented compactly in the linguistic structure, therefore implicitness plays an important role in the cognitive component of the content (Nefedova, 2000: 58).

Another aspect of the functioning of implicitness in F. M. Dostoevsky's idiodiscourse is its semi-cultural significance, since the precondition for the emergence of implicit content is the connection between objects and phenomena of extra-linguistic activity, which is reflected in the relationship between language and culture. The perception of the cultural code allows us to consider the problem of interpreting implicitness in the field of hermeneutics, which includes the methods of the semiotic approach and literary criticism of the text (Nefedova, 2000).

The semantic approach in combination with the text-centric approach in the study of implicitness allows us to conclude that the implicative potential of linguistic units is fully manifested precisely because of the intertext and intra-text interaction with the participation of the reader (Dolbina, 2011: 8). Responsible for this are mental processes such as conjectures and assumptions, which provide a deepening and expansion of the information content of sign linguistic units during the communicative activity of the writer with the reader (Barysheva, 2016: 42).

Conclusions. The appeal to the implicative potential allows us to trace the mechanisms of its generation and actualization, which are associated with the process of interpretation, which affects the perception of information by the addressee. The implicative potential of an artistic detail is due to the structural and semantic features of the constituent lexical units and the conditions for their implementation in works. Perception factors are associated with the socio-cultural environment, education, character of a person, his worldview and personal experience and form different models of perception, interpretation and reaction. If we assume that implicitness is a feature of F. M. Dostoevsky's idio discourse and his signs (concepts, images, other semantic dominants), which reflect the presence of hidden authorial meanings, then the question arises about the embodiment of implicitness and its interaction with the integrity, coherence and coherence of idiodiscourse ... Based on this, we believe that implicitness in F. M. Dostoevsky's idiodiscourse is a 


\section{Ukrainian sense. 2020. ISSN 2313-4437}

complex, multifaceted and universal linguistic phenomenon responsible for creating depth of subtext and new information, not expressed verbally, but at the same time conjectured (remembered), understood by the reader with the help of various linguistic means, background knowledge and thinking processes and is of great importance for understanding the meaning of the text. Thus, the peculiarities of the interaction of implicitness with explicitness and its manifestations in the writer's idiodiscourse make it possible to draw a conclusion about the originality of Dostoevsky's idiodiscourse. Further study of the levels and degree of perception by the reader of the implied texts will allow to distinguish implicitness into low, medium and high depending on the degree of expression of hidden information. The study of idiodiscourse as an individual refraction in the structure of the literary personality of a writer provides an opportunity for scientific study and modeling of the linguistic portrait of the literary personality as such.

\section{REFERENCES}

Anokhina, N. V. (2010). Implitsitnost kak komponent struktury soderzhaniya teksta i sostavlyayushchaya protsessov ego ponimaniya [Implicitness as a component of the structure of the content of the text and a component of the processes of its understanding. Extended abstract of Candidate's thesis. Ufa [in Russian].

Arnold, I. V. (1982). Implikatsiya kak priyem postroyeniya teksta [Implication as a method of constructing a text]. Voprosy yazykoznaniya - Linguistic issues, 4, 83-91 [in Russian].

Arustamyan, Zh. N. (2011). Implitsitnost kak interaktsionalnaya kategoriya i mekhanizmy eye realizatsii vo frantsuzskom yazyke [Implicitness as an interactional category and the mechanisms of its implementation in French]. Extended abstract of Candidate's thesis. Voronezh [in Russian].

Bagdasaryan, V. Kh. (1983). Problema implitsitnogo : logiko-metodologicheskiy analiz [The problem of the implicit: logical and methodological analysis]. Erevan: Izd-vo AN ArmSSR [in Russian].

Barysheva, A. I. (2016). Implitsitnost kak svoystvo publitsisticheskogo teksta [Implicitness as a property of a journalistic text]. Extended abstract of Candidate's thesis. Ufa [in Russian].

Bondarko, A. B. (2006). Eksplitsitnost / implitsitnost v obshchey sisteme kategorizatsii semantiki [Explicitness / implicitness in the general system of semantics categorization]. Eksplitsitnost / implitsitnost vyrazheniya smyslov: materialy mezhdunarodnaya nauchnaya konferenciya - Explicit / implicit expression of meanings: materials of an international scientific conference, 23-34 [in Russian].

Dolbina, V. K. (2011). Poniattia movnoi implitsytnosti na suchasnomu etapi rozvytku linhvistyky [The concept of linguistic implicitness at the present stage of development of linguistics]. Aktualni pytannia filolohii - Topical issues of philology, 1, 173-176 [in Ukrainian].

Dolinin, K. A. (1983). Implicitnoe soderzhanie vyskazyvaniya [Implicit content of the statement]. Voprosy yazykoznaniya - Linguistic issues, 6, 37-47 [in Russian].

Ermakova, E. V. (2010). Implicitnost' v hudozhestvennom tekste (na materiale anglijskoj i russkoj psihologicheskoj prozy) [Implicitness in a literary text (based on the material of English and Russian psychological prose)]. Extended abstract of Candidate's thesis. Saratov [in Russian].

Fedosyuk, M. Yu. (1988). Neyavnye sposoby peredachi informacii $v$ tekste : uchebnoe posobie po speckursu [Implicit ways of conveying information in the text: a tutorial for a special course]. Moscow: MGPI [in Russian].

Hvorostin, D. V. (2006). Skrytye komponenty smysla vyskazyvaniya: princip vyyavleniya [Hidden components of the meaning of a statement: the principle of revealing. Extended abstract of Candidate's thesis. Chelyabinsk [in Russian].

Ivanishyn, N. Ya. (2006). Leksychni zasoby formuvannia implitsytnosti v dramaturhiinomu teksti (na materiali ukrainskoi dramy pochatku KhKh stolittia) [Lexical means of forming implicitness in a dramatic text (based on the Ukrainian drama of the early 20th century)]. Extended abstract of Candidate's thesis. Ivano-Frankivsk [in Ukrainian]. 


\section{Ukrainian sense. 2020. ISSN 2313-4437}

Kornienko, E. R. (1996). Smyslovoe vospriyatie $i$ ponimanie inoyazychnogo teksta [Semantic perception and understanding of a foreign language text]. Moscow: GPI Iskona [in Russian].

Kuharenko, V. A. (1988). Interpretaciya teksta [Interpreting text]. Moscow: Prosveshchenie [in Russian].

Kuharenko, V. A. (Ed.). (1980). Individual'no-hudozhestvennyj stil' i ego issledovanie [Individual artistic style and its research]. Kyiv; Odessa: Vishcha shkola [in Russian].

Lisochenko, L. M. (1992). Vyskazyvaniya s implicitnoj semantikoj (logicheskij, yazykovoj $i$ pragmaticheskij aspekty) [Statements with implicit semantics (logical, linguistic and pragmatic aspects)]. Rostov-na-Donu: Izd-to Rostov-na-Donu universitet [in Russian].

Miloserdova, E. V. (2011). Implicitnost' kak lingvopragmaticheskaya kategoriya i ee rol' v raznyh tipah diskursa [Implicitness as a linguopragmatic category and its role in different types of discourse]. Vestnik Tomskogo gosudarstvennogo universiteta - Tomsk State University Bulletin, 12 (104), 727-732 [in Russian].

Nefedova, L. A. (2000). Kognitivno-deyatel'nostnyj aspekt implikativnoj kommunikacii [Cognitive-activity aspect of implicative communication]. Chelyabinsk: Chelyabinskij gosudarstvennyy universitet [in Russian].

Nikitin, M. V. (1988). Osnovy lingvisticheskoj teorii znacheniya [Fundamentals of the linguistic theory of meaning]. Moscow: Vysshaya shkola [in Russian].

Ostin, Dzh. L. (2011). Filosofiya yazyka [Philosophy of language]. Moscow: Editorial URSS [in Russian].

Parshin, P. B., \& Pirogova, Y. K. (2000). Rechevoe vozdejstvie: osnovnye sfery i raznovidnosti [Speech impact: main areas and varieties]. Reklamnyj tekst: semiotika i lingvistika Promotional text: semiotics and linguistics (pp. 55-75) Moscow: Mezhdunarodnyj institut reklamy, Izdatel'skij dom Grebennikova [in Russian].

Prosyanikova, O. I. (2004). Aktualizaciya implicitnosti hudozhestvennoj detali v tekstah psihologicheskoj prozy [Actualization of the implicitness of artistic detail in the texts of psychological prose]. Extended abstract of Candidate's thesis. Sankt-Peterburg [in Russian].

Shalud'ko, I. A. (2016). Implicitnost' kak princip tekstoobrazovaniya i analiza literaturnogo tekst [Implicitness as a principle of text formation and analysis of a literary text]. Doctor's thesis. Sankt-Peterburg [in Russian].

Yermolenko, S. Ya. (2001). Ukrainska mova. Korotkyi tlumachnyi slovnyk linhvistychnykh terminiv [Ukrainian language. Brief explanatory dictionary of linguistic terms]. Kyiv: Lybid [in Ukrainian].

\section{Анотація}

Постановка проблеми. Опис понять “текст”, “стиль”, “ідіолект”, “ідіостиль” свідчить про те, наскільки не збігається їхній зміст. У процесі сприйняття та розуміння тексту пресуппозиція та імплікація, що є складниками імпліщитної інформації всього тексту, мають бути відновлені реципієнтом повністю або частково, інакше сприйняття тексту буде неповним, частковим або не буде досягнуто загалом. Отже, механізм реконструкиї імплічитності є одним з найважливіших й універсальних закономірностей розуміння твору.

Мета статmі - визначити поняття “ідіостиль" і проаналізувати різні підходи до иього поняття через особливості творчої манери письма Ф. М. Достоєвського, зокрема категорії імпліцитності.

Методи дослідження. У роботі вдаємося до таких методів, як описовий та мовностилістичний аналіз, адже питання ідіостилю в останнє десятиліття набуло комплексного характеру, відповідно до чого аналіз ідіостилю Ф. М. Достоєвського потребує багаторівневого підходу. Методи дослідження зумовлені концепцією вивчення иілісності художнього образу художнього твору, що визначаємо за лінією перетину семантики $i$ стилістики. 


\section{Ukrainian sense. 2020. ISSN 2313-4437}

Основні результати дослідження. У статті надано загальну репрезентацію основних особливостей і механізмів текстотворення, щзо фіксують характерологічні риси ідіостилю Ф. М. Достоєвського, зокрема місие та роль категорії імпліцитності. Дискурс сприймаємо як характер викладення творів письменника та його відмінні мовні особливості. Ідіодискурс визнаємо як комунікативно-художній простір автора та читача, який у сукупності та взаємодії всіх свойх аспектів, утворює иілісне комунікативне середовище, у яке поринають усі, хто бере участь у процесі комунікативної діяльності. Описано принципи співвідношення дискурс - текст - ідіодискурс - ідіостиль, визначено ідіостиль як об'єкт дослідження мовознавства, проаналізовано ідіостиль та мовну картину світу Ф. М. Достоєвського, розглянуто категорію імпліцитності в ідіодискурсі письменника, розмежовано поняття імпліциттності, підтексту, імплікаиії та пресуппозииї.

Висновки і перспективи. Звернення до імплікативного потенціалу деталі дало змогу простежити механізми його породження $i$ актуалізації, щзо пов'язані з процесом інтерпретації, який впливає на перцепцію інформації адресатом. Чинники сприймання пов'язані із соиіально-культурним середовищем, освітою, характером людини, його світоглядом і особистим досвідом й утворюють різні моделі сприйняття, інтерпретаиії та реакиії. Імпліцитність в ідіодискурсі Ф. М. Достоєвського - ие складне, багатопланове та універсальне лінгвістичне явище, щуо відповідає за створення глибини підтексту та нової інформації, яке не висловлене вербально, але при иьому домислюється (пригадується), розуміється читачем за допомогою різноманітних мовних засобів, фонових знань і процесів мислення та має неабияке значення для сприйняття змісту та смислу тексту. Отже, особливості взаємодї імпліциттності з експліщзитністю та ї̈ вияви в ідіодискурсі письменника дають змогу зробити висновок про своєрідну рису ідіодискурсу Ф. М. Достоєвського.

Ключові слова: стиль, ідіостиль, ідіолект, текст, імпліџฺтність, експліичитність, підтекст.

\section{Abstract}

Background. The description of the concepts "text", "style", "idiolect", "idiostyle" indicates how much their content does not coincide. In the process of perceiving and understanding the text, the presuppositions and implications, which are components of the implicit information of the entire text, must be restored by the recipient in whole or in part, otherwise the understanding of the text will be incomplete, partial or not achieved at all. Therefore, the mechanism for reconstructing implicitness is one of the most important and universal laws of understanding a work.

The purpose of the article is to define the concept of "idiostyle" and consider various approaches to this concept due to the peculiarities of the creative manner of writing of F. M. Dostoevsky, in particular the category of implicitness.

Methods. In this work, we resort to such methods as descriptive and linguo-stylistic analysis, because the question of idiostyle in the last decade has acquired a complex character, in accordance with which the analysis of F. M. Dostoevsky's idiostyle requires a multilevel approach. The research methods are determined by the concept of studying the integrity of the artistic image of a work of art, determined by the intersection of semantics and stylistics.

Results. The article gives a general representation of the main features and mechanisms of text formation, exposing the characterological features of F.M. Dostoevsky's idiostyle, in particular the place and role of the category of implicitness. We perceive discourse as the nature of the presentation of the writer's works and his distinctive linguistic features. We recognize idio discourse as the communicative and artistic space of the author and the reader, which, in the aggregate and interaction of all its aspects, forms an integral communicative environment into which everyone who participates in the process of communicative activity immerses. The principles of the discourse - text - idiodiscourse - idiostyle correlation are described, idiostyle is defined as an object of linguistics research, the idiostyle and linguistic picture of the world of 
Ukrainian sense. 2020. ISSN 2313-4437

F.M. Dostoevsky are analyzed, the category of implicitness in the writer's idiodiscourse is considered, the concepts of implicitness, subtext, implication and presupposition are distinguished.

Discussion. The appeal to the implicative potential of the detail made it possible to trace the mechanisms of its generation and actualization associated with the process of interpretation, which affects the perception of information by the addressee. Perception factors are associated with the socio-cultural environment, education, character of a person, his worldview and personal experience and form different models of perception, interpretation and reaction. Implicitness in F. M. Dostoevsky's idiodiscourse is a complex, multifaceted and universal linguistic phenomenon that is responsible for creating depth of subtext and new information, not expressed verbally, but at the same time conjectured (remembered), understood by the reader using various linguistic means, background knowledge, and processes of thinking and is of great importance for understanding the meaning and meaning of the text. Thus, the peculiarities of the interaction of implicitness with the explorer and its manifestation in the writer's idiodiscourse make it possible to draw a conclusion about a peculiar feature of Dostoevsky's idiodiscourse.

Keywords: style, idiostyle, idiolect, text, implicitness, explicitness, subtext. 